\title{
Diagnosis and prognosis of acute hamstring injuries in athletes
}

\author{
Gino M. M. J. Kerkhoffs • Nick van Es • \\ Thijs Wieldraaijer • Inger N. Sierevelt • \\ Jan Ekstrand • C. Niek van Dijk
}

Received: 17 December 2011/ Accepted: 10 May 2012/Published online: 24 May 2012

(C) The Author(s) 2012. This article is published with open access at Springerlink.com

\begin{abstract}
Purpose Identification of the most relevant diagnostic and prognostic factors of physical examination and imaging of hamstring injuries in (elite) athletes.

Methods A literature search was conducted in MEDLINE and EMBASE for articles between 1950 and April 2011. A survey was distributed among the members of the European Society of Sports Traumatology, Knee Surgery and Arthroscopy, which focused on physical examination, prognosis, imaging and laboratory tests of hamstring injuries in (elite) athletes.

Results Medical history, inspection and palpation of the muscle bellies and imaging are most valuable at the initial assessment according to the literature. Experts considered medical history, posture and gait inspection, inspection and palpation of muscle bellies, range of motion tests, manual muscle testing, referred pain tests and imaging to be most important in the initial assessment of hamstring injuries. Magnetic resonance imaging (MRI) is preferred over ultrasonography and should take place within 3 days posttrauma. Important prognostic factors are injury grade, length of the muscle tear on MR images, MRI-negative injuries and trauma mechanism.

Conclusions Posture and gait inspection, inspection and palpation of muscle bellies, range of motion tests, manual
\end{abstract}

G. M. M. J. Kerkhoffs $(\bowtie) \cdot$ N. van Es · T. Wieldraaijer ·

I. N. Sierevelt · C. N. van Dijk

ESSKA Sports Committee, Department of Orthopedic Surgery,

Academic Medical Center, 1105 AZ Amsterdam,

The Netherlands

e-mail: g.m.kerkhoffs@amc.nl

J. Ekstrand

Department of Medical and Health Sciences,

Linköping University, Linköping, Sweden muscle testing and referred pain tests within 2 days posttrauma were identified as the most relevant diagnostic factors. Level of evidence Literature review and expert opinion, Level V.

Keywords Hamstring strain injury - Sports injury · Physical examination · Imaging

\section{Introduction}

Hamstring injuries are frequent in sports like football [117, 21, 27, 46, 59, 60], Australian rules football [43, 52], sprinting [65], American football [20] and rugby [10]. Considering the explosive character of sprinting, it is not surprising that the incidence of injuries $(0.87 / 1,000 \mathrm{~h}$ of exposure) is comparable to the incidence in contact sports (0.92-0.96/1,000 $\mathrm{h}$ of exposure) [17, 18, 65]. At the top level, professional football team of 25 players can expect about 7 hamstring injuries per season [16]. These injuries frequently cause a significant loss of time from competition and have a high recurrence rate (12-43\%) [11, 17, 21, 24, $27,30,35,39,46,52,56,58]$. Elite football players sustaining a hamstring injury cannot participate in competition for a mean of 14 days [17]. The need for a quick and accurate diagnosis and prognosis of hamstring injuries in elite sports is evident and has been given greater emphasis. The number of games in elite sports has increased and the stakes are higher [63]. However, there is little evidence for the diagnostic and prognostic value of several physical tests [50,61] and discussion continues on the optimal imaging technique $[1,8,13,14,34,50,61]$. The objective of this study was to identify the most relevant diagnostic and prognostic aspects of physical examination and additional studies of hamstring injuries in (elite) athletes. 


\section{Materials and methods}

\section{Literature review}

A comprehensive literature study was conducted for articles between January 1950 and April 2011 on the diagnosis and prognosis of hamstring injuries. The strategies that were used consisted of searching online databases (MEDLINE and EMBASE) and scanning reference lists. The search terms used in MEDLINE were hamstring* or thigh[MeSH] combined with the MeSH-terms 'Sprains and Strains/diagnosis', 'Muscle, Skeletal/injuries', 'Magnetic resonance imaging' or 'Ultrasonography'. In EMBASE, the terms 'hamstring'/exp/mj' or 'thigh/exp/mj' and 'injury'/exp combined with prognos*, diagnos*, assess*, ultrasonograph*, ultrasound, mri, 'magnetic resonance imaging' or imag* were searched for. Articles concerning medical history, physical examination, prognosis and imaging of hamstring injuries were selected.

\section{Expert opinion}

As part of a project of the Sports Committee of the European Society of Sports Traumatology, Knee Surgery and Arthroscopy (ESSKA), ESSKA Members $(n=800)$ were invited by e-mail to participate in an English web-based survey in June 2009. The survey focused on the physical examination, prognosis, imaging and laboratory tests for hamstring injuries in (elite) athletes. The questions were formulated by the authors on the basis of a comprehensive literature review. The survey was a mixture of open questions, multiple choice questions and Likert-scale questions. The five options from which the respondents could choose in the Likert-scale questions were (1) not important, (2) of little importance, (3) moderately important, (4) important and (5) very important. Additional information was provided on the way in which the physical tests were carried out. A pilot survey was distributed among the orthopaedic surgeons of the Academic Medical Center in Amsterdam in order to identify indistinct, irrelevant and missing questions. One week after the first invitation to take part, a reminder was sent by e-mail to the ESSKA members in which they were asked to participate in the survey.

\section{Statistic analysis}

Data were analysed using SPSS version 16.0 (Chicago, USA). Results were mainly presented in a descriptive way as frequencies with corresponding percentages and averages with standard deviations. Likert scales were dichotomised by combining options 1 and 2 and options 3-5 to, respectively, the categories 'not important' and 'important'.

\section{Results}

One hundred and forty ESSKA members (18\% response rate) from 34 countries with 18 (SD 9.6) years of experience completed the questionnaire. The selected articles from the literature search are categorised according to the type of article and the level of evidence in Tables 1, 2 .

Timing of initial physical examination

Traditionally, the clinical assessment of hamstring injuries is based on a thorough medical history and physical examination consisting of posture and gait inspection, inspection and palpation of muscle bellies, 'range of motion' tests (ROM tests) and manual muscle testing. In the literature, the initial assessment is often carried out within $12 \mathrm{~h}$ to 2 days post-injury [5, 50, 58, 61]. Advantages of an assessment shortly post-injury are the possibility of quick intervention and a more reliable medical history. However, possible signs of swelling and ecchymosis may arise a few days later and consequently may not be noticed at the initial examination $[4,12,31,62] .82 \%$ of the respondents stated that the initial clinical assessment of an (elite) athlete with a suspected hamstring injury should take place within 2 days. This is confirmed in recent work where it is advised to measure active ROM at the end of the second day [38].

\section{Palpation}

Palpation helps identify the site of injury in cranio-caudal direction, because of possible involvement of the free proximal tendon, and determines the injured muscles (lateral: $\mathrm{m}$. biceps femoris, medial: $\mathrm{m}$. semitendinosus and/or $\mathrm{m}$. semimembranosus). Injuries in the $\mathrm{m}$. biceps femoris [13] and more cranially palpated injuries [5] might correlate with a longer rehabilitation interval.

\section{Flexibility}

Flexibility in acute and sub-acute phase was addressed. Flexibility is tested by means of hamstring ROM tests. In case of a hamstring injury, the range of motion of the hip and the knee of the injured leg is significantly decreased compared to the healthy leg [4]. However, the flexibility of the hip in the acute situation is often influenced by pain as a consequence of which the test may be less accurate. Active ROM is decreased in the acute phase of the injury and it is advised to be measured at the end of the second day [38]. Use of the classic 'sit-and-reach' test is discouraged in the literature as the testing result is influenced by spinal mobility (i.e. lumbal flexion), leg length, scapular abduction and stretch on the peripheral nerves by dorsiflexion of 
Table 1 Overview of the literature review source articles

\begin{tabular}{|c|c|c|}
\hline Article & Article design (type) & $\begin{array}{l}\text { Level of } \\
\text { evidence }\end{array}$ \\
\hline Allen et al. [1] & Expert opinion/background & $\mathrm{V}$ \\
\hline Arnason et al. [2] & $\begin{array}{l}\text { Epidemiological review } \\
\text { Retrospective cohort study }\end{array}$ & II \\
\hline Arnason et al. [3] & $\begin{array}{l}\text { Original article } \\
\text { Prospective therapeutic study }\end{array}$ & II \\
\hline Askling et al. [4] & $\begin{array}{l}\text { Original article } \\
\text { Prospective prognostic study }\end{array}$ & II \\
\hline Askling et al. [5] & $\begin{array}{l}\text { Original article } \\
\text { Prognostic case series }\end{array}$ & II \\
\hline Askling et al. [6] & $\begin{array}{l}\text { Original article } \\
\text { Prognostic case series }\end{array}$ & II \\
\hline Askling et al. [7] & $\begin{array}{l}\text { Original article } \\
\text { Prognostic case series }\end{array}$ & IV \\
\hline $\begin{array}{l}\text { Bencardino et al. } \\
\text { [8] }\end{array}$ & Expert opinion/background & $\mathrm{V}$ \\
\hline $\begin{array}{l}\text { Blankerbaker et al. } \\
\text { [9] }\end{array}$ & Expert opinion/background & $\mathrm{V}$ \\
\hline Brooks et al. [10] & $\begin{array}{l}\text { Original article } \\
\text { Cohort study (prevention) }\end{array}$ & III \\
\hline Carling et al. [11] & $\begin{array}{l}\text { Epidemiological review } \\
\text { Prognostic case series }\end{array}$ & II \\
\hline Cohen et al. [12] & Literature review/background & $\mathrm{V}$ \\
\hline Connell et al. [13] & $\begin{array}{l}\text { Original article } \\
\text { Diagnostic case series }\end{array}$ & I \\
\hline Davis [14] & Expert opinion/background & $\mathrm{V}$ \\
\hline Ekstrand et al. [15] & $\begin{array}{l}\text { Original article } \\
\text { Prospective cohort study }\end{array}$ & II \\
\hline Ekstrand et al. [16] & $\begin{array}{l}\text { Original article } \\
\text { Prospective two-cohort study }\end{array}$ & II \\
\hline Ekstrand et al. [17] & $\begin{array}{l}\text { Original article } \\
\text { Prospective cohort study }\end{array}$ & II \\
\hline Ekstrand et al. [18] & $\begin{array}{l}\text { Original article } \\
\text { Prospective cohort study }\end{array}$ & II \\
\hline Ekstrand et al. [19] & $\begin{array}{l}\text { Original article } \\
\text { Prospective cohort study }\end{array}$ & II \\
\hline Elliott et al. [20] & $\begin{array}{l}\text { Descriptive epidemiology study } \\
\text { Prospective cohort study }\end{array}$ & II \\
\hline $\begin{array}{l}\text { Engebretsen et al. } \\
{[21]}\end{array}$ & $\begin{array}{l}\text { Original article } \\
\text { Prospective cohort study }\end{array}$ & II \\
\hline $\begin{array}{l}\text { Fleckenstein et al. } \\
\text { [22] }\end{array}$ & $\begin{array}{l}\text { Original article } \\
\text { Diagnostic case series (descriptive) }\end{array}$ & III \\
\hline $\begin{array}{l}\text { Fleckenstein et al. } \\
\text { [23] }\end{array}$ & Expert opinion/background & $\mathrm{V}$ \\
\hline Gibbs et al. [24] & $\begin{array}{l}\text { Original article } \\
\text { Prospective diagnostic study }\end{array}$ & I \\
\hline Gielen et al. [25] & $\begin{array}{l}\text { Expert opinion/background } \\
\text { Descriptive chapter }\end{array}$ & $\mathrm{V}$ \\
\hline
\end{tabular}

Table 1 continued

\begin{tabular}{lll}
\hline Article & Article design (type) & $\begin{array}{l}\text { Level of } \\
\text { evidence }\end{array}$ \\
\hline
\end{tabular}

Guerrero et al. [26] Original article

III

Prognostic case series

Hägglund et al. Original article

I

Prospective prognostic study

Heiderscheit et al. Expert opinion/background

[29]

Heiser et al. [30] Original article

Retrospective cohort study

Klingele et al. [31] Original article

\section{Kornberg et al.}

Retrospective cohort study

Koulouris et al. [33]

Koulouris et al. Original article

III [34]

Koulouris et al.

Therapeutic cohort study

[35]

Lempainen et al.

Original article

Retrospective cohort study

Expert opinion/background

$$
\text { [36] }
$$

Original article

Prognostic cohort study

[36]

Original article

Retrospective case series

Liemohn et al. [37] Original article

Therapeutic case series

Malliaropoulos

Original article

et al. [38]

Malliaropoulos et al. [39]

Prognostic cohort study

Original article

Prognostic cohort study

Martínez Amat et al. [40]

Original article

Diagnostic cohort study

Miñarro et al. [41] Original article

Diagnostic cohort study

Nikolaou et al. [42] Biomechanical and histological IV evaluation of muscle

Orchard et al. [43] Original article

III

Retrospective epidemiologic study

Orchard et al. [44] Expert opinion/background V

Peetrons [45] Expert opinion/background V

Petersen et al. [46] Original article II

Prospective cohort study

Puranen et al. [47] Expert opinion/background V

Sallay et al. [48] Original article III

Descriptive case series

Sarimo et al. [49] Original article IV

Schneider-Kolsky Original article I

et al. [50] Diagnostic cohort study

Schneider-Kolsky Author's reply V et al. [51] 
Table 1 continued

\begin{tabular}{|c|c|c|}
\hline Article & Article design (type) & $\begin{array}{l}\text { Level of } \\
\text { evidence }\end{array}$ \\
\hline Seward et al. [52] & $\begin{array}{l}\text { Original article } \\
\text { Prospective cohort study }\end{array}$ & II \\
\hline Shellock et al. [53] & Expert opinion/background & $\mathrm{V}$ \\
\hline $\begin{array}{l}\text { Slavotinek et al. } \\
\text { [54] }\end{array}$ & $\begin{array}{l}\text { Original article } \\
\text { Prospective RCT }\end{array}$ & II \\
\hline Sorichter et al. [55] & $\begin{array}{l}\text { Original article } \\
\text { Retrospective case-control study }\end{array}$ & III \\
\hline Verrall et al. [56] & $\begin{array}{l}\text { Original article } \\
\text { Prospective prognostic cohort study }\end{array}$ & II \\
\hline Verrall et al. [57] & $\begin{array}{l}\text { Original article } \\
\text { Prospective cohort study }\end{array}$ & II \\
\hline Verrall et al. [58] & $\begin{array}{l}\text { Original article } \\
\text { Prospective cohort study }\end{array}$ & II \\
\hline Volpi et al. [59] & $\begin{array}{l}\text { Epidemiological review } \\
\text { Retrospective cohort study }\end{array}$ & III \\
\hline Walden et al. [60] & $\begin{array}{l}\text { Original article } \\
\text { Prospective cohort study }\end{array}$ & I \\
\hline Warren et al. [61] & $\begin{array}{l}\text { Original article } \\
\text { Prospective observational study }\end{array}$ & II \\
\hline Wood et al. [62] & Expert opinion/background & V \\
\hline Woods et al. [63] & $\begin{array}{l}\text { Epidemiological review } \\
\text { Prospective cohort study }\end{array}$ & II \\
\hline Woods et al. [64] & $\begin{array}{l}\text { Epidemiological review } \\
\text { Prospective cohort study }\end{array}$ & II \\
\hline Yeung et al. [65] & $\begin{array}{l}\text { Original article } \\
\text { Prospective cohort study }\end{array}$ & II \\
\hline Zeren et al. [66] & $\begin{array}{l}\text { Original article } \\
\text { Diagnostic cohort study }\end{array}$ & III \\
\hline
\end{tabular}

Level of evidence is rendered as ranging from $\mathrm{I}$ to $\mathrm{V}$ in accordance with guidelines from the centre for evidence-based medicine, Oxford, UK

the ankle joint $[37,41]$. Knee active range of motion deficit $48 \mathrm{~h}$ after a unilateral posterior thigh muscle injury is an objective and accurate measurement, predicting recovery time in elite athletes [38].

Flexibility tests were pointed out as important by a majority of the respondents. The 'sit-and-reach' test was considered to be important despite the above-mentioned negative advice given in the literature. No difference in importance was found between active and passive ROM tests (n.s).

\section{Strength}

Strength of the hamstring muscles can be tested by means of knee flexion and hip extension against resistance. Bilateral comparison is preferred to identify decreased strength of the injured muscle as a result of pain and/or
Table 2 Summary of the articles used for this literature review and level of evidence

\begin{tabular}{|c|c|c|c|c|c|c|}
\hline \multirow[t]{2}{*}{ Article type } & \multirow[t]{2}{*}{ Number } & \multicolumn{5}{|c|}{ Level of evidence } \\
\hline & & I & II & III & IV & V \\
\hline Total & 65 & 6 & 26 & 12 & 6 & 15 \\
\hline \multicolumn{7}{|l|}{ Original article } \\
\hline $\begin{array}{l}\text { Epidemiological } \\
\text { review }\end{array}$ & 7 & & 5 & 2 & & \\
\hline Prospective & 30 & 6 & 21 & 2 & 1 & \\
\hline Retrospective & 13 & & & 8 & 5 & \\
\hline Literature review & 1 & & & & & 1 \\
\hline $\begin{array}{l}\text { Expert opinion/ } \\
\text { background }\end{array}$ & 13 & & & & & 13 \\
\hline Author's reply & 1 & & & & & 1 \\
\hline
\end{tabular}

fibre disruption [4]. An alternative to measuring the strength of the hamstring muscles is the 'take-off-the-shoe' test (TOST) (or 'hamstring-drag' test) in which the patient is asked to take-off the shoe of the injured leg in a standing position with the help of the foot of the healthy leg [66]. Although this test is potentially a valuable addition to the physical examination, the true value should be studied by comparison with magnetic resonance imaging (MRI) and recurrence rates [51].

\section{Referred pain}

An acute disc prolapse at the L5/S1 level may present with hamstring and/or calf pain and limitations in hip joint flexibility, which may mimic a muscle strain. Subtle lumbosacral canal impingement of the L5 nerve root however may in fact also be a common underlying basis for the agerelated predisposition towards hamstring injuries [44]. The distinction between real hamstring injuries and backrelated' or 'neural' hamstring injuries can be made by the assessment of referred pain with help of an MRI scan [44, 56]. If the distinction remains difficult, imaging-guided cortisone injections to the lumbosacral canal region (L5 nerve root) is a relatively painless and complication-free outpatient procedure with quick recovery that can be used to distinguish the hamstring-spine dilemma.

Pain felt over the area of the ischial tuberosity and radiating down the back of the thigh is often labelled as the 'hamstring syndrome' [47].

\section{Laboratory tests}

Traditional biological markers creatine kinase (CK), lactate dehydrogenase (LDH), myoglobin $(\mathrm{Mb})$ and uric acid should not be used for the diagnosis and prognosis of muscle injuries because of their low sensitivity and specificity [55]. More research is needed to determine the real 
diagnostic and prognostic value of potential markers, such as 'fast myosin heavy chains' (fast MHC) [26], 'skeletaltroponin I' (sTnI) [55] and 'alfa-actin' [40].

Few of the respondents thought that laboratory tests can be of diagnostic or prognostic importance.

The results of the survey are shown in Table 3.

\section{Imaging}

The imaging provides information on the nature and extent of hamstring injuries. The length of a muscle tear on MR images or the cross-sectional area of the muscle tear on ultrasonography (US) is valuable for estimating the convalescent period $[13,19,24,35,50,52] .88 \%$ of the respondents in this study use imaging for hamstring injuries in (elite) athletes.

\section{Imaging technique}

MRI and US are the most suitable imaging techniques for depicting hamstring injuries [8, 34]. Connell et al. [13] concluded that MRI and US are equally useful in diagnosing hamstring injuries at baseline. However, MRI is more sensitive for identifying minimal injuries, with less than $5 \%$ of muscle involved: the radiological definition of a grade-I muscle injury [13, 33, 45]. When imaging is indicated, MRI is used in 40-77\% of cases, both MRI and US in $7-40 \%$ and US only in $20-53 \%$ of cases [10, 17, 19, 64]. The most important advantages and disadvantages of both imaging techniques are presented in Table 4.

Table 3 Importance of different physical tests and additional studies for hamstring injuries in (elite) athletes according to experts

\begin{tabular}{lll}
\hline Test & $\begin{array}{l}\text { Important } \\
(\%)\end{array}$ & $\begin{array}{l}\text { Not } \\
\text { important } \\
(\%)\end{array}$ \\
\hline Palpation to identify the site of injury & 97 & 3 \\
Palpation to identify the injured muscle(s) & 95 & 5 \\
Knee flexion against resistance & 94 & 6 \\
Inspection of the posterior thigh & 93 & 7 \\
Posture and gait inspection & 86 & 14 \\
Hip extension against resistance & 86 & 14 \\
Assessing referred pain & 86 & 14 \\
Active straight leg raise & 85 & 15 \\
Sit-and-reach test & 83 & 17 \\
Passive knee extension & 81 & 19 \\
Active knee extension & 80 & 20 \\
Passive straight leg raise & 80 & 20 \\
Take-off-the-shoe test/hamstring-drag test & 79 & 21 \\
Prognostic laboratory tests & 13 & 87 \\
Diagnostic laboratory tests & 4 & 96 \\
\hline
\end{tabular}

Table 4 Advantages and disadvantages of MRI and US as imaging technique for hamstring injuries

\begin{tabular}{lll}
\hline Qualities & MRI & US \\
\hline Low costs [13] & - & ++ \\
Independence of the quality and experience of the & ++ & - \\
$\quad$ physician [13] & & \\
Ease of use & \pm & ++ \\
Ease of use for prognosis [13] & ++ & + \\
Sensitivity for low-grade injuries [13, 33] & + & \pm \\
Diagnosis of avulsion fractures [33] & + & \pm \\
Reproducibility & ++ & \pm \\
Dynamic assessment & - & ++ \\
Availability & \pm & ++ \\
Evaluation of superficial structures [33] & + & ++ \\
Evaluation of deep structures & ++ & \pm \\
Correct reflection of the extent of the injury [13] & ++ & \pm \\
Assessment time & \pm & ++ \\
Follow-up imaging [13] & ++ & + \\
\hline$++=$ much applicable, $+=$ applicable, $\pm=$ less & applicable, \\
$-=$ not applicable & &
\end{tabular}

Time of imaging

There is currently no consensus in the literature on the ideal moment of imaging of hamstring injuries. Ekstrand et al. [19] are in favour of MRI within 24-48 h post-trauma, whereas Gielen et al. [25] argue that a hamstring injury can only be correctly graded $48-72 \mathrm{~h}$ post-trauma. Signs of muscle injury on MR images are mainly seen on fat-suppressed T2 images or 'short-tau inversion recovery' images (STIR) and are most evident at $24 \mathrm{~h}$ to 5 days post-trauma $[22,23,53]$. In prospective studies, MRI is often used out $2-5$ days post-trauma $[13,35,58]$. Since the amount of oedema is histologically maximal after $24 \mathrm{~h}$ and already decreases after $48 \mathrm{~h}$ [42], imaging 1-2 days post-trauma seems to be the best moment.

The respondents prefer imaging within 3 days posttrauma for MRI (66\%) and for US (79\%).

Follow-up imaging

MRI is more sensitive for follow-up imaging than US [13]. Follow-up imaging is useful in the case of complications and in order to follow the progression of the rehabilitation and consequently to support the decision for sports resumption for (elite) athletes [9]. After 6 weeks in 34-94 \% of all cases, signs of hamstring injury are still noticeable on MR images [5]. The ideal moment of followup imaging differs in every single case and is therefore difficult to generalise.

$66 \%$ of the respondents use follow-up imaging in the case of persisting bad rehabilitation and $61 \%$ to assess the 
progression of the rehabilitation. In total, $91 \%$ of the respondents use follow-up imaging for hamstring injuries in (elite) athletes.

\section{Prognostic factors}

An accurate prognosis can be obtained on the basis of a thorough clinical assessment [50].

Different classification systems are provided in the literature. A clinical classification system resulting from the treatment for 165 elite track and field athletes with acute, first-time unilateral hamstring muscle strains was proposed in 2010. Strains were classified into 4 grades (I, II, III and IV) based on knee active range of motion deficit at $48 \mathrm{~h}$ [38].

Imaging is a valuable addition. There is the classic radiological grading system of a hamstring injury with grade I (minimal muscle damage with $<5 \%$ of muscle length involved) or II (partial rupture with 5-50\% of muscle length involved) on MRI or US to correspond with the rehabilitation period [13, 19, 24, 50, 52]. Grade III hamstring injuries (complete rupture or avulsion fracture) are serious injuries resulting in a convalescent period of 3 months up to 1.5 years, often requiring surgery [31, 36, 48 , 49]. In 2002, an additional grading systems was introduced, specifically for US, grade 0 (normal US appearance), grade 1 (subtle ultrasound findings), grade 2 and grade 3 injuries (partial and complete muscle tears) [45]. In general, the grading should be done by a team consisting of an orthopaedic surgeon and/or a sports medicine physician and a radiologist.

A substantial part of supposed hamstring injuries are negative on MRI (14-45\%) [24, 50, 56, 57]. In these cases, the symptoms are probably not the result of muscle fibre disruption, but are caused by referred pain (e.g. from the lumbar spine) or abnormal neural tension [32, 44, 47]).

It has been described that hamstring injuries that result from excessive slow-speed stretching require a much longer convalescent period compared to hamstring injuries sustained during high-speed running. In the former type of injury, the $\mathrm{m}$. semimembranosus and the free proximal tendon are often involved, resulting in a rehabilitation period of 31-50 weeks. [6, 7].

Athletes sustaining a recurrent hamstring injury have a longer convalescent period compared to a first-time hamstring injury $[10,17,18,35,39]$. The time to return to sports after re-injury was-depending on the injury grade-on average 1.9-11 days longer [10, 17, 35, 39]. Over $50 \%$ of re-injuries occur within 1 month after the initial injury [10]. This emphasises the risk of an early return to sport after a hamstring injury.

The factors mentioned in the literature associated with a longer rehabilitation period are compared with the expert opinion in Table 5.
Table 5 Prognostic factors during the injury period associated with a longer rehabilitation period for hamstring injuries in (elite) athletes
$++=$ multiple randomised controlled trials (RCT) (strong evidence), $+=$ one RCT (moderate evidence), $\pm=$ contradiction in the literature, $-=$ no evidence

\begin{tabular}{|c|c|c|}
\hline Factors associated with a longer rehabilitation period & Literature & $\begin{array}{l}\text { Expert } \\
\text { opinion }\end{array}$ \\
\hline Complete rupture or avulsion fracture $[12,31,48,62]$ & ++ & ++ \\
\hline $\begin{array}{l}\text { Greater length of muscle tear on MR images or larger cross-sectional } \\
\text { area of muscle tear on ultrasound images }[13,24,50,54]\end{array}$ & ++ & ++ \\
\hline MRI-positive hamstring injury $[13,24,57]$ & ++ & + \\
\hline Recurrent hamstring injury $[10,17,18,35,39]$ & + & ++ \\
\hline $\begin{array}{l}\text { Persisting pain/restriction at ROM tests, strength tests and sport } \\
\text { exercises }\end{array}$ & + & ++ \\
\hline Injury resulting from excessive slow-speed stretching [4] & + & + \\
\hline Persisting signs of injury on follow-up imaging [5] & + & + \\
\hline Injury to the $\mathrm{m}$. biceps femoris [13] & \pm & + \\
\hline Sports type [5] & \pm & + \\
\hline More cranially palpated injury [5] & \pm & + \\
\hline Large and deep haematoma & - & ++ \\
\hline Hamstring injury involving the free proximal tendon [6] & + & - \\
\hline $\begin{array}{l}\text { Higher subjective pain score at the time of injury on a Visual } \\
\text { Analogue Scale (VAS) [57] }\end{array}$ & + & - \\
\hline Being unable to walk pain-free within $24 \mathrm{~h}$ of injury [61] & + & - \\
\hline Long period until initial treatment & - & + \\
\hline $\begin{array}{l}\text { Low quality of the rehabilitation programme and minimal willingness } \\
\text { of the patient to rehabilitate }\end{array}$ & - & + \\
\hline
\end{tabular}




\section{Discussion}

In this study, we identified posture and gait inspection, inspection of the muscle bellies, location and extent of the muscle tear, flexibility, strength of the hamstrings and assessing referred pain within 2 days as most relevant diagnostic factors of the physical examination. This is in line with the evidence from recent literature. Consensus between literature and experts was also observed for the use of MRI to identify injuries with a longer rehabilitation time: (1) greater length of muscle tear on MR images, (2) MRI-positive injuries and (3) persistent signs on follow-up injuries.

Although both MRI and US techniques are used, most experts prefer MRI to US. MRI is more sensitive than US $[13,33]$, easier to use for prognostic purposes [13, 52] and less operator-dependent [33]. Consequently, MRI should be given the preference over US as imaging technique at the initial assessment. Although it has to be stated that US remains valuable in many cases because of its low costs, availability, dynamic character and secondly, that US is indeed still quite operator-dependent.

Consensus between literature and experts was also found for the interpretation that apart from the MRI results, trauma mechanism and injury grade are important prognostic factors and that laboratory tests are of minimal diagnostic and prognostic value.

There was no consensus between literature and experts on the interpretation of a large and deep haematoma: experts interpret a large and deep haematoma as an important factor associated with a longer rehabilitation period; however, literature does not provide the evidence for this. This is also observed for a longer period to initial treatment and low quality of the rehabilitation programme. All three above-mentioned factors seem logical; however, literature does not support nor deny the prognostic value of these factors. There was also no consensus on the value of higher VAS score [58] nor being able to walk pain-free within $24 \mathrm{~h}$ of injury [61], experts do not (yet) seem to link these factors to a longer rehabilitation period. Reason for

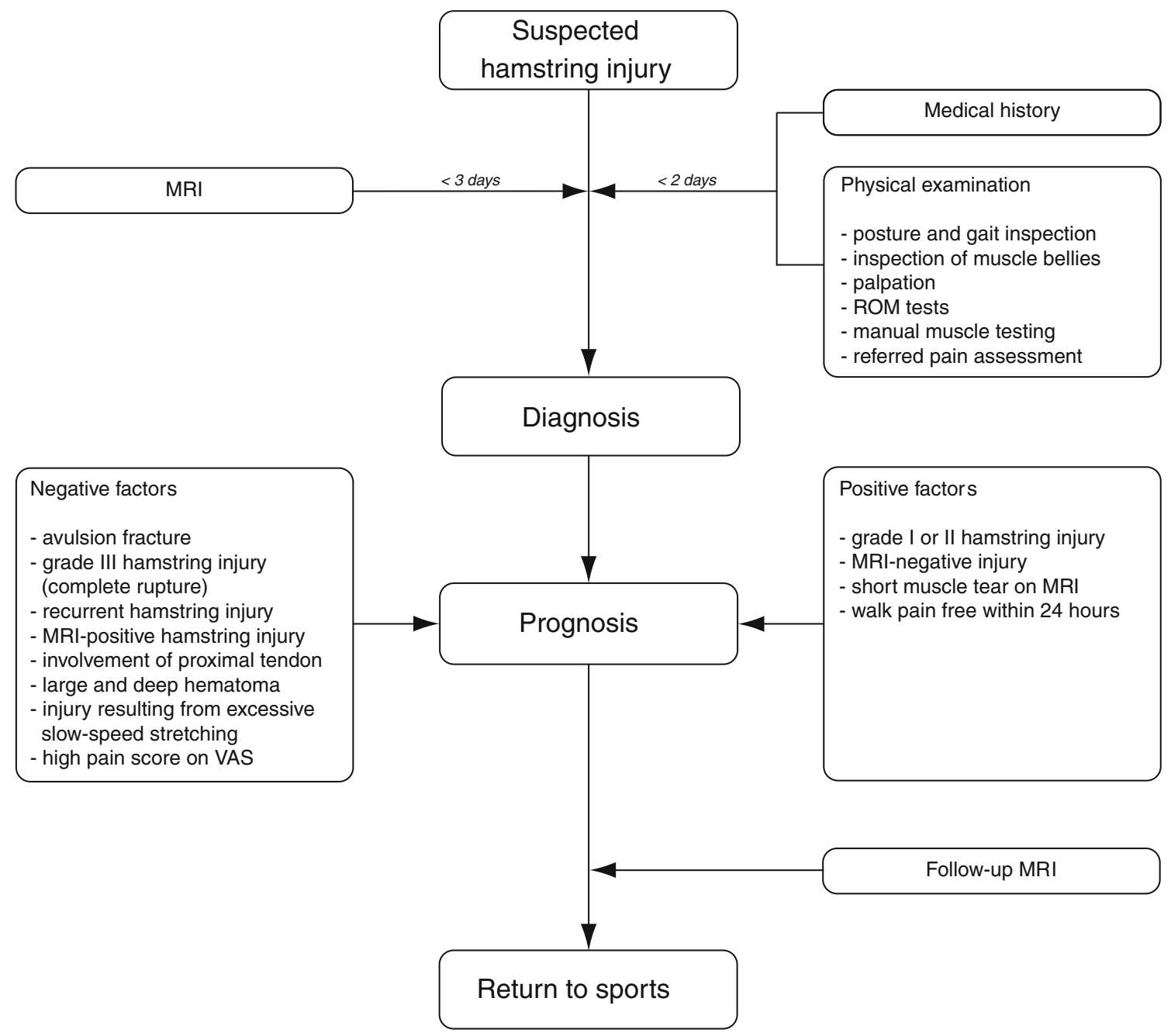

Fig. 1 Guideline for diagnosing hamstring injuries and estimating the convalescent period in elite athletes 
this difference between literature and experts could be the subjective nature of these findings or simply that these findings are not widely known or accepted by other experts yet.

There are obvious limitations of this research. Since many prospective studies evaluated hamstring injuries in only one type of sports, there is a selection bias $[2,3,10$, $11,15-17,20,21,27,43,46,52,59,60,64,65]$. The question rises whether the conclusions of these studies can be extrapolated to other sports types. In our survey, experts were not asked to specify for the sports types with which they deal in their daily practice. Caution is therefore recommended when adopting the results of this study.

Also, there is the limited value of a questionnaire with low response rate, again a selection bias [28]; however, we feel that the research benefits from the information provided by the selection of ESSKA members with interest in muscle injuries that answered the questionnaire.

We feel that there is a definite need for further research in this field. First, all prognostic factors identified in this review should be validated in a prospective cohort and even better in different cohorts of active sports participants, so the difference between the different sport types can also be monitored. Second, the anatomy of the hamstring (injuries) can be re-evaluated to see whether we can identify important prognostic factors on a basic level. Third, imaging provides numerous keystones to improve the understanding of the extent of the hamstring injury and to link this to an accurate prognosis: ideal moment of initial assessment, use of follow-up imaging in decision-making, US versus MRI, optimalisation of MRI modalities.

With this combination of best evidence from the literature and experts from the field, the most relevant and explicit diagnostic and prognostic factors of physical examination, imaging and additional studies of hamstring injuries in (elite) athletes were identified and an assessment protocol for hamstring injuries in (elite) athletes (Fig. 1) was proposed. In this way, it was attempted to provide a guideline for diagnosing hamstring injuries and estimating the convalescent period in (elite) athletes.

\section{Conclusion}

Physical examination of an athlete with suspected acute hamstring injury should take place within 2 days posttrauma and consists of posture and gait inspection, location and extent of the muscle tear, flexibility and strength of the hamstrings and assessing referred pain.

MRI as imaging technique for acute hamstring injuries in elite athletes is preferred over ultrasound by both the experts and recent literature mainly based on its greater sensitivity for minor injuries and the ease of use for an accurate prognosis.
Important prognostic factors related to a longer rehabilitation period are MRI-positive muscle tears, larger extent of the muscle tear as seen on MRI, recurrent hamstring injury and injury mechanism.

Acknowledgments We thank all ESSKA colleagues who participated in the questionnaire and the ESSKA Sports committee colleagues for their feedback on the research protocol.

Conflict of interest No competing interests or funding reported.

Open Access This article is distributed under the terms of the Creative Commons Attribution License which permits any use, distribution, and reproduction in any medium, provided the original author(s) and the source are credited.

\section{References}

1. Allen GM (2007) Ultrasound in sports medicine-a critical evaluation. Eur J Radiol 62:79-85

2. Arnason A, Gudmundsson A, Dahl HA, Jóhannsson E (1996) Soccer injuries in Iceland. Scand J Med Sci Sports 6:40-45

3. Arnason A, Andersen TE, Holme I, Engebretsen L, Bahr R (2008) Prevention of hamstring strains in elite football: an intervention study. Scand J Med Sci Sports 18:40-48

4. Askling C, Saartok T, Thorstensson A (2006) Type of acute hamstring strain affects flexibility, strength, and time to return to pre-injury level. Br J Sports Med 40:40-44

5. Askling CM, Tengvar M, Saartok T, Thorstensson A (2007) Acute first-time hamstring strains during high-speed running: a longitudinal study including clinical and magnetic resonance imaging findings. Am J Sports Med 35:197-206

6. Askling CM, Tengvar M, Saartok T, Thorstensson A (2007) Acute first-time hamstring strains during slow-speed stretching: clinical, magnetic resonance imaging, and recovery characteristics. Am J Sports Med 35:1716-1724

7. Askling CM, Tengvar M, Saartok T, Thorstensson A (2008) Proximal hamstring strains of stretching type in different sports: injury situations, clinical and magnetic resonance imaging characteristics, and return to sport. Am J Sports Med 36:1799-1804

8. Bencardino JT, Mellado JM (2005) Hamstring injuries of the hip. Magn Reson Imaging Clin N Am 13:677-690, vi

9. Blankenbaker D, De Smet AA (2004) MR-imaging of muscle injuries. Appl Rad 33:14-17

10. Brooks JH, Fuller CW, Kemp SP, Reddin DB (2006) Incidence, risk, and prevention of hamstring muscle injuries in professional rugby union. Am J Sports Med 34:1297-1306

11. Carling C, Le Gall F, Orhant E (2011) A four-season prospective study of muscle strain reoccurrences in a professional football club. Res Sports Med 19:92-102

12. Cohen S, Bradley J (2007) Acute proximal hamstring rupture. J Am Acad Orthop Surg 15:350-355

13. Connell DA, Schneider-Kolsky ME, Hoving JL, Malara F, Buchbinder R, Koulouris G, Burke F, Bass C (2004) Longitudinal study comparing sonographic and MRI assessments of acute and healing hamstring injuries. AJR Am J Roentgenol 183:975-984

14. Davis KW (2008) Imaging of the hamstrings. Semin Musculoskelet Radiol 12:28-41

15. Ekstrand J, Gillquist J (1983) Socces injuries and their mechanisms: a prospective study. Med Sci Sports Exerc 15:267-270

16. Ekstrand J, Timpka T, Hägglund M (2006) Risk of injury in elite football played on artificial turf versus natural grass: a prospective two-cohort study. Br J Sports Med 40:975-980 
17. Ekstrand J, Hägglund M, Waldén M (2011) Epidemiology of muscle injuries in professional football (Soccer). Am J Sports Med 39:1226-1232

18. Ekstrand J, Hägglund M, Waldén M (2011) Injury incidence and injury patterns in professional football-the UEFA injury study. Br J Sports Med 45:553-558

19. Ekstrand J, Healy JC, Waldén M, Lee JC, English B, Hägglund M (2012) Hamstring muscle injuries in professional football: the correlation of MRI findings with return to play. Br J Sports Med 46:112-117

20. Elliott MC, Zarins B, Powell JW, Kenyon CD (2011) Hamstring muscle strains in professional football players: a 10-year review. Am J Sports Med 39:843-850

21. Engebretsen AH, Myklebust G, Holme I, Engebretsen L, Bahr R (2010) Intrinsic risk factors for hamstring injuries among male soccer players: a prospective cohort study. Am J Sports Med 38:1147-1153

22. Fleckenstein JL, Weatherall PT, Parkey RW, Payne JA, Peshock RM (1989) Sports-related muscle injuries: evaluation with MR imaging. Radiology 172:793-798

23. Fleckenstein JL, Shellock FG (1991) Exertional muscle injuries: magnetic resonance imaging evaluation. Top Magn Reson Imaging 3:50-70

24. Gibbs NJ, Cross TM, Cameron M, Houang MT (2004) The accuracy of MRI in predicting recovery and recurrence of acute grade one hamstring muscle strains within the same season in Australian Rules football players. J Sci Med Sport 7:248-258

25. Gielen JL, Robinson P, Van Dyck P, Van der Stappen A, Vanhoenacker FM (2007) Muscle injuries. In: Vanhoenacker FM, Maas MM, Gielen JL (eds) Imaging of orthopedic sports injuries, 1st edn. Springer, New York, pp 15-39

26. Guerrero M, Guiu-Comadevall M, Cadefau JA, Parra J, Ballius R, Estruch A, Rodas G, Bedini JL, Cussó R (2008) Fast and slow myosins as markers of muscle injury. $\mathrm{Br} \mathrm{J}$ Sports Med 42:581-584

27. Hägglund M, Waldén M, Ekstrand J (2006) Previous injury as a risk factor for injury in elite football: a prospective study over two consecutive seasons. Br J Sports Med 40:767-772

28. Hasson G, Keeney S, McKenna H (2000) Research guidelines for the Delphi survey technique. J Adv Nurs 32:1008-1015

29. Heiderscheit BC, Sherry MA, Silder A, Chumanov ES, Thelen DG (2010) Hamstring strain injuries: recommendations for diagnosis, rehabilitation, and injury prevention. J Orthop Sports Phys Ther 40:67-81

30. Heiser TM, Weber J, Sullivan G, Clare P, Jacobs RR (1984) Prophylaxis and management of hamstring muscle injuries in intercollegiate football players. Am J Sports Med 12:368-370

31. Klingele KE, Sallay PI (2002) Surgical repair of complete proximal hamstring tendon rupture. Am J Sports Med 30:742-746

32. Kornberg C, Lew P (1989) The effect of stretching neural structures on grade one hamstring injuries. J Orthop Sports Phys Ther 10:481-487

33. Koulouris G, Connell D (2003) Evaluation of the hamstring muscle complex following acute injury. Skeletal Radiol 32:582-589

34. Koulouris G, Connell D (2005) Hamstring muscle complex: an imaging review. Radiographics 25:571-586

35. Koulouris G, Connell DA, Brukner P, Schneider-Kolsky M (2007) Magnetic resonance imaging parameters for assessing risk of recurrent hamstring injuries in elite athletes. Am J Sports Med 35:1500-1506

36. Lempainen L, Sarimo J, Heikkila J, Mattila K, Orava S (2007) Distal tears of the hamstring muscles: review of the literature and our results of surgical treatment. Br J Sports Med 41:80-83

37. Liemohn W, Martin SB, Pariser GL (1997) The effect of ankle posture on sit-and-reach test performance. J Strength Cond Res 11:239-241
38. Malliaropoulos N, Papacostas E, Kiritsi O, Papalada A, Gougoulias N, Maffulli N (2010) Posterior thigh muscle injuries in elite track and field athletes. Am J Sports Med 38:1813-1819

39. Malliaropoulos N, Isinkaye T, Tsitas K, Maffulli N (2011) Reinjury after acute posterior thigh muscle injuries in elite track and field athletes. Am J Sports Med 39:304-310

40. Martínez Amat A, Marchal Corrales JA, Rodríguez Serrano F, Boulaiz H, Prados Salazar JC, Hita Contreras F, Caba Perez O, Carrillo Delgado E, Martín I, Aranega Jimenez A (2007) Role of alpha-actin in muscle damage of injured athletes in comparison with traditional markers. Br J Sports Med 41:442-446

41. Miñarro PA, Andújar PS, García PL, Toro EO (2007) A comparison of the spine posture among several sit-and-reach test protocols. J Sci Med Sport 10:456-462

42. Nikolaou PK, Macdonald BL, Glisson RR, Seaber AV, Garrett WE Jr (1987) Biomechanical and histological evaluation of muscle after controlled strain injury. Am J Sports Med 15:9-14

43. Orchard J, Seward H (2002) Epidemiology of injuries in the Australian Football League, seasons 1997-2000. Br J Sports Med 36:39-44

44. Orchard JW, Farhart P, Leopold C (2004) Lumbar spine region pathology and hamstring and calf injuries in athletes: is there a connection? Br J Sports Med 38:502-504

45. Peetrons P (2002) Ultrasound of muscles. Eur Radiol 12:35-43

46. Petersen J, Thorborg K, Nielsen MB, Hölmich P (2010) Acute hamstring injuries in Danish elite football: a 12-month prospective registration study among 374 players. Scand J Med Sci Sports 20:588-592

47. Puranen J, Orava S (1988) The hamstring syndrome. A new diagnosis of gluteal sciatic pain. Am J Sports Med 16:517-521

48. Sallay PI, Friedman RL, Coogan PG, Garrett WE (1996) Hamstring muscle injuries among water skiers. Functional outcome and prevention. Am J Sports Med 24:130-136

49. Sarimo J, Lempainen L, Mattila K, Orava S (2008) Complete proximal hamstring avulsions: a series of 41 patients with operative treatment. Am J Sports Med 36:1110-1115

50. Schneider-Kolsky ME, Hoving JL, Warren P, Connell DA (2006) A comparison between clinical assessment and magnetic resonance imaging of acute hamstring injuries. Am J Sports Med 34:1008-1015

51. Schneider-Kolsky M, Warren P, Connell D (2007) Author's reply on comment on: a comparison between clinical assessment and magnetic resonance imaging of acute hamstring injuries. Am $\mathbf{J}$ Sports Med 35:149-150

52. Seward H, Orchard J, Hazard H, Collinson D (1993) Football injuries in Australia at the elite level. Med J Aust 159:298-301

53. Shellock FG, Fleckenstein JL (2000) Muscle physiology and pathophysiology: magnetic resonance imaging evaluation. Semin Musculoskelet Radiol 4:459-479

54. Slavotinek JP, Verrall GM, Fon GT (2002) Hamstring injury in athletes: using MR imaging measurements to compare extent of muscle injury with amount of time lost from competition. AJR Am J Roentgenol 179:1621-1628

55. Sorichter S, Mair J, Koller A, Gebert W, Rama D, Calzolari C, Artner-Dworzak E, Puschendorf B (1997) Skeletal troponin I as a marker of exercise-induced muscle damage. J Appl Physiol 83:1076-1082

56. Verrall GM, Slavotinek JP, Barnes PG, Fon GT, Spriggins AJ (2001) Clinical risk factors for hamstring muscle strain injury: a prospective study with correlation of injury by magnetic resonance imaging. Br J Sports Med 35:435-439

57. Verrall GM, Slavotinek JP, Barnes PG, Fon GT (2003) Diagnostic and prognostic value of clinical findings in 83 athletes with posterior thigh injury: comparison of clinical findings with magnetic resonance imaging documentation of hamstring muscle strain. Am J Sports Med 31:969-973 
58. Verrall GM, Slavotinek JP, Barnes PG, Fon GT, Esterman A (2006) Assessment of physical examination and magnetic resonance imaging findings of hamstring injury as predictors for recurrent injury. J Orthop Sports Phys Ther 36:215-224

59. Volpi P, Melegati G, Tornese D, Bandi M (2004) Muscle strains in soccer: a five-year survey of an Italian major league team. Knee Surg Sports Traumatol Arthrosc 12:482-485

60. Walden M, Hagglund M, Ekstrand J (2005) UEFA champions League study: a prospective study of injuries in professional football during the 2001-2002 season. Br J Sports Med 39:542-546

61. Warren P, Gabbe BJ, Schneider-Kolsky M, Bennell KL (2010) Clinical predictors of time to return to competition and of recurrence following hamstring strain in elite Australian footballers. Br J Sports Med 44:415-419

62. Wood DG, Packham I, Trikha SP, Linklater J (2008) Avulsion of the proximal hamstring origin. J Bone Jt Surg Am 90:2365-2374
63. Woods C, Hawkins R, Hulse M, Hodson A (2002) The football association medical research programme: an audit of injuries in professional football-analysis of preseason injuries. Br J Sports Med 36:436-441

64. Woods C, Hawkins RD, Maltby S, Hulse M, Thomas A, Hodson A (2004) The football association medical research programme: an audit of injuries in professional football-analysis of hamstring injuries. Br J Sports Med 38:36-41

65. Yeung SS, Suen AM, Yeung EW (2009) A prospective cohort study of hamstring injuries in competitive sprinters: preseason muscle imbalance as a possible risk factor. Br J Sports Med 43:589-594

66. Zeren B, Oztekin HH (2006) A new self-diagnostic test for biceps femoris muscle strains. Clin J Sport Med 16:166-169 